\title{
Incidence and Risk Factors of Emergence Delirium After Anesthesia in Elderly Patients at a Postanesthesia Care Unit in Ethiopia: Prospective Observational Study [Removal]
}

\author{
Assefa MT, Chekol WB, Melesse DY, Nigatu YA. Patient \\ Relat Outcome Meas. 2021;12:23-32.
}

The following article has been removed from the Dove Medical Press journal, Patient Related Outcome Measures:

Assefa MT, Chekol WB, Melesse DY, Nigatu YA, "Incidence and Risk Factors of Emergence Delirium after Anesthesia in Elderly Patients at a Postanesthesia Care Unit in Ethiopia: Prospective
Observational Study" (https://doi.org/10.2147/PROM. S297871).

Published online: 9 February 2021.

The Editor and Publisher are removing the article from publication in Patient Related Outcome Measures as the article used the State-Trait Anxiety Inventory Tool without purchasing a licence and reproduced the StateTrait Anxiety Inventory table without authorization from the copyright holder, Mind Garden, Inc.

\section{Publish your work in this journal}

Patient Related Outcome Measures is an international, peer-reviewed, open access journal focusing on treatment outcomes specifically relevant to patients. All aspects of patient care are addressed within the journal and practitioners from all disciplines are invited to submit their work as well as healthcare researchers and patient support groups.
The manuscript management system is completely online and includes a very quick and fair peer-review system. Visit http://www. dovepress.com/testimonials.php to read real quotes from published authors. 